\title{
FINDING MEANING IN THE PAST: REINTERPRETATION OF THE LATE ROMAN ARTIFACT, THE GOLDEN RING WITH A CARNELIAN INTAGLIO FROM THE MUSEUM OF GEORGIA
}

\author{
EKA AVALIANI \\ International Black Sea University, Tbilisi (Georgia) \\ eavaliani@ibsu.edu.ge
}

\begin{abstract}
This paper offers a novel interpretation of the luxury golden ring with a carnelian intaglio depicting a woman's profile and an engraved Greek inscription, BACIAICCA

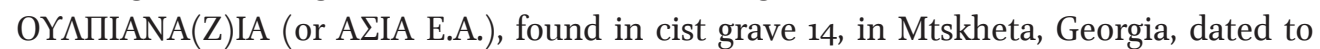
the Roman period, the zrd century AD. In consideration of the then contemporary political situation in the Mediterranean and Roman East, through the putting and interpreting sources into broad historical context, the author identifies the female individual as the Roman Empress Ulpia Severina. The very inclusion of royal woman within public propaganda during this period signifies her prominence within, and significance outside of, the imperial metropolis. This deliberate inclusion proved to the public that this empress was not mere figurehead but could have been a very influential person in the Empire.
\end{abstract}

KEYWORDS: The luxury golden ring with a carnelian intaglio, Roman period, an engraved Greek inscription, Roman Orient, a Roman empress, the Roman royal woman.

\section{Introduction}

One particular artifact that caught our attention is located in the Museum of Georgia, in Archeological Collection, inventory no. o1-6-X-1611. It is the luxury golden ring with a carnelian intaglio depicting a woman's profile wearing an

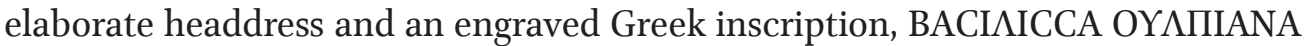
(Z) IA (or A IIA E.A.) provides the name of a portrayed individual. 
The ring was discovered during archaeological excavations in cist grave no.14, in Mtskheta, Georgia and dated to the Roman period, the 3 rd century AD. ${ }^{1}$ The results of archaeological investigation was published at a later date in 2004. ${ }^{2}$

T. Kauchtschischwili deciphered the Greek inscription. According to

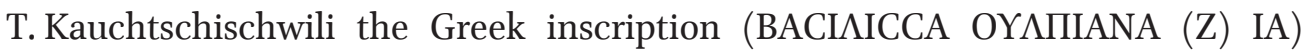
should have been divided into several words and translated as follows: ' $\beta \alpha \sigma i \lambda \iota \sigma \sigma \alpha$

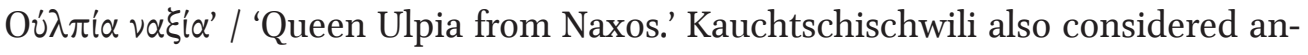
other version of translation: 'Queen Ulpia ruler.' ${ }^{3}$

The suggested interpretation of this inscription, the given identification of personality as the above-mentioned female, Queen/ Bacilicca Ulpia and her relation to the island of Naxos raises many questions with regard to the historical reliability of such assumptions. In consideration of the then contemporary (the 3rd century AD) historical-political situation in the Mediterranean and Near East, that is the extension of the Late Roman imperial rule on transregional and regional levels, it is unlikely that any Basilissa from the Greek island of Naxos can be perceived as a historical figure from the local dynasty. The suggested second version of the translation - "Queen Ulpia ruler" - looks like truthful because of the

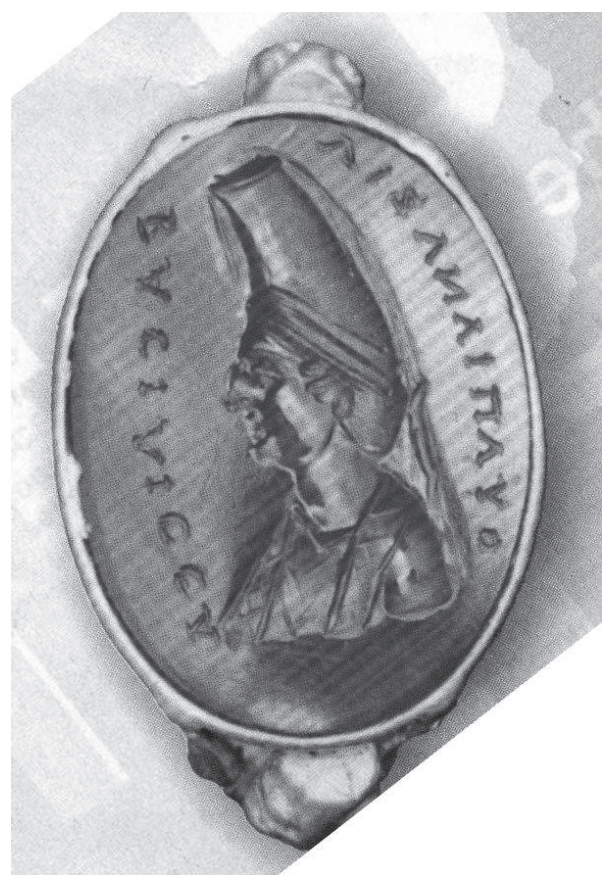
factual relationship between these two elements, the proper name, and title, but between these two elements, the missing interpretation of some letters ( NA (Z) IA) makes the translation incomplete and imperfect.

I presume that the above-mentioned portrait type recalls the sources of authority used by the emperor in presenting the image of the "royal wives and daughters" to justify their position. As well as the portrait has incorporated elements of matronly virtue, but also attributes of specific goddesses. The paper offers a reinterpretation of an engraved Greek inscription and analysis of origins and context of the artifact. Through the inclusion of the artifact into broad histor-

\footnotetext{
${ }^{1}$ For a discussion on the problems of dating, see Apakidze et al. 2004, 104-123.

${ }^{2}$ Apakidze et al. 2004, 104-123. For the location of the tomb no.14, see Apakidze et al. 2004, 104-105.

${ }^{3}$ Kauchtschischwili 2003, 136-142.
} 
ical context, the author identifies the female individual as one of the then contemporary Roman Empress. This article considers the nature of the relationship between the royal image, the identity, the iconography, and the text in the Roman Orient.

\section{A Carnelian Intaglio, Portrait of the Lady, Interpretation and Parallels}

The grave in Mtskheta contained very rich materials and included a wide variety of artifacts. In the tomb, there were some 24 pieces of gold, silver, bronze, iron, glass, etc. A golden ring, tanged gold coin pendants with a bust of Faustina II (ca. 130-176, a Roman empress, wife of the emperor Marcus Aurelius) and Lucilla (ca. 149-181, a Roman empress, married to Lucius Verus), among others, are notable in that collection. The tomb No. 14, due to its archaeological data, which include a high amount of luxurious goods of foreign origin, must have belonged to a member of the local ruling élite.

A gold signet-ring with a reddish carnelian gem-intaglio (cf. the picture above) was found near the left hand of the deceased person. The engraved bust of a woman on the oval bezel of the ring is a representative example of the Late Roman portrait, a work reminiscent of Hellenistic models. The woman appears with a strong jaw and a large aquiline nose with sagging flesh on her cheeks and a small chin. Her neck appears to be slightly fleshy with a distinct fold in the middle. Her eyes are puffy, and her lips are not quite pursed, but certainly do not form a hint of a smile.

This woman' well-styled hair with the curls over ears has been gathered at the nape of the neck and fixed up inside the back of the head. Her hairstyle creates an effect of wealth, leisure, and style, which was, as far as feminine ideals went, the pinnacle of female Romanitas.

The woman wears an unusual type of headgear, which resembles a Phrygian hat or bonnet with a veil covering the back of body. This hat with its conical shape also bears resemblance to the Hittite hats - a high polos represented in Yazilikaya (not far from Bogazkoy) and to a polos (high cylindrical hat) with a veil worn by goddess Kubaba / Kybele/ Cybele. ${ }^{4}$ Later depictions of the polos, worn both by men and women, survive in hundreds of images from Archaic to Roman times on a variety of monuments ranging from sculpture to mosaics. The woman's elaborate headdress appears as a combination of a Phrygian hat, a high polos and also bashlyk, all of those were popular headdresses in Anatolia and Syria. ${ }^{5}$

\footnotetext{
${ }^{4}$ Şare 2011, 41-52.

${ }^{5}$ Butcher 2003, 330-31. Kybele/ Cybele was one of many cults that appeared in Rome. The cult of Cybele eventually achieved official recognition during the reign of Emperor Claudius (41-44 CE). Ultimately, her appeal as an agrarian goddess would enable her to
} 
The polos was also popular among the Eastern Greeks who populated the western coast of Anatolia until the Roman times. Some surviving statues and several coins show Artemis Ephesia wearing simple polos on her head, sometimes with a veil attached. ${ }^{6}$

The personification of piety of Roman empresses towards the gods, family, and state, is often shown with a veil on coins. The veil, known as the palla in Latin and the himation in Greek, was a fairly common component of Greek and Roman dress, both for men and women. We can also see the emperor, presenting as sacrificing magistrate with his head veiled by his toga. The religious role of this garment was significant. It invoked religious sanctity and piety and was often worn by gods and goddesses. ${ }^{7}$

The evidence from Anatolia indicates a variety in veil and veiling styles-the veil types include those worn with a polos, the polos-veil. ${ }^{8}$ The veil and veiling in Asia Minor and Syria was a typical attribute and custom for the élite women. The most elaborate costumes occur in the third century, where the veil is drawn over a highly decorated and jeweled turban. The combination of turban and veil may have been influenced by styles at Edessa (Upper Mesopotamia, the city was under direct Roman rule in ca. 242) and Hatra (Northern Mesopotamia, the city was under direct Roman rule in the first half of the 3rd century) where taller headdresses were found. ${ }^{9}$

Depicted female from the gold signet-ring is dressed in the Roman stola, a garment for women worn under the palla and over the under tunic. The stola depicted with sleeves.

The portrait tells us what the artist took great care to represent the lady as an imposing and significant person, her expression having something of oriental solemnity but also recalls Hellenistic elaborate style. The Hellenistic tradition remained strong during the Roman Imperial period and one may presume that this portrait was related to the Roman royal woman, who was depicted in the GrecoRoman style with a mixture of oriental features.

find adherents in northern Africa as well as Transalpine Gaul. In Rome, Cybele's popularity continued to flourish, partially due to her spring festival held in March (some sources say April) called the Megalensia. The Cult of Kybele/ Cybele lasted until the 4th century AD.

${ }^{6}$ Budin, 2016, 21.

${ }^{7}$ Tracene 2011, 161.

${ }^{8}$ Şare 2011, 53 .

${ }^{9}$ Butcher, 2003, 33 . 


\section{The Recovering Historical and Geographical Context, the Reinterpretation of Inscription}

The local historical context indicates that the cist grave no.14 dated to the Roman period, the 3rd century AD. Though some discovered artifacts date back to the earlier periods of the Roman Empire e.g. the tanged gold coin pendants with a bust of Faustina II ca.130-176 and Lucilla ca.149-181. In spite of the fact that there are certain gaps in dating, the artifacts are related to the Late Roman imperial periods. These objects are used as a lens through which to speculate about the existence of possible political, regional, and even transregional networks between the then contemporary Iberian Kingdom ${ }^{10}$ and the Roman Empire.

However, Roman power was never particularly firm in Iberia. Eastern Georgia generally accepted imperial protection while Colchis was administered as a Roman province. Iberia was under the suzerainty of the Sasanian Empire during the reign of Shapur I (240/2 - 270/2 AD). However, it is remarkable that the Romans regained Caucasia briefly under Emperor Aurelian (270-275) and again, in 283, when Carus defeated the Sassanid armed forces."

At the height of the Roman Empire, Greece came into imperial possession. Administrative units in the Roman Empire were represented through senatorial and imperial provinces. ${ }^{12}$ Proconsuls (usually, these men were former praetors) governed the senatorial provinces and typically served twelve months. Only the rich provinces Asia and Africa were entitled to proconsul provinces, whose governers were the ex-consuls. Legati Augusti pro praetore - these men served in the emperor's provinces/imperial provinces with the armies. Usually, their term in office lasted thirty-six months, although the emperor Tiberius preferred longer terms for their service.

The Roman Greece i.e. the Roman province of Achaia as generally agreed to have occurred in $27 \mathrm{BC}$ as the starting point for a history of Roman Greece. ${ }^{13}$ Originally Achaia was a senatorial province, although in AD 15 it was transferred, together with the province of Macedonia, to the imperial province of Moesia. ${ }^{14}$ However Naxos the part of the Cyclades (an island group in the Aegean Sea) related to the other Late Roman province of the islands (Lat. Provincia Insularum or Insulae) consisting of several islands in the Aegean. The Cyclades group consists

\footnotetext{
${ }^{10}$ In Greco-Roman sources, Iberia (Ancient Greek: 'I $\beta$ pía Iberia; Latin: Hiberia) corresponds to the Georgian kingdom of Kartli.

${ }^{11}$ Suny 1994, 15 .

${ }^{12}$ Millar 1966, 156-166.

${ }^{13}$ Alcock 1993, 9 .

${ }^{14}$ Alcock 1993, 16.
} 
of a small complex of 32 small islands. In $117 \mathrm{AD}$ the Cyclades was the part of the senatorial provinces, governed directly by the Senate.

Earlier, during the civil war, Antony had made the Rhodians commit themselves to him by offering them some islands, Andros, Tenos, Naxos and Myndos, which they accepted. ${ }^{15}$ It is not known when the Rhodians lost control of the islands, which they had acquired from Antony, possibly when Augustus visited Rhodes in 30 BC but possibly later when Augustus had more time to consider the settlement of the east. ${ }^{16}$ Though the inscription from the sanctuary of Helios at Rhodes (the first century BC) confirms that Augustus was the highest political

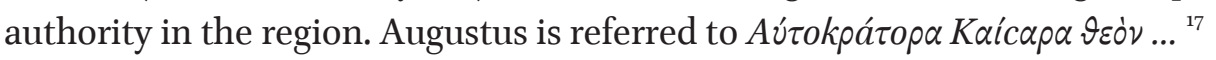

During Vespasian's reign (69-79 AD), the islands had apparently been added to the province of Asia. ${ }^{18}$ According to Bouras ${ }^{19}$ the islands that were off the coast usually belonged to the closest province and the central islands of the Aegean, like the Cyclades, belong to the Province of Asia, as well as the islands off the coast of Asia Minor. The annexation of the Cyclades to the province of Asia has been argued by Étienne, ${ }^{20}$ but the partition of the islands among the provinces of Achaia and Asia has been suggested by Accame. ${ }^{21}$

Under Diocletian (284-305 AD), the 'province of the islands' was part of the

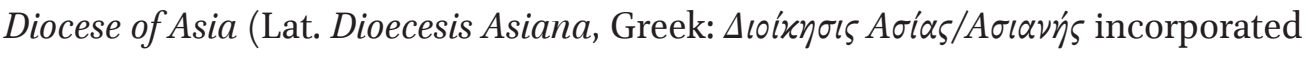
the provinces of western Asia Minor and the islands of the eastern Aegean Sea) and was subordinate to the Praetorian prefecture of the East that included the Cyclades. In Late Antiquity the 'province of the islands' included twenty cities: Rhodes, Amorgos, Andros, Astypalaia, Chios, Ios, Kos, Melos, Methymna, Mytilene, Naxos, Paros, Petelos, Proselene, Samos, Siphnos, Tenedos, Tenos and Thera. ${ }^{22}$ Rhodes was the capital of the province, whose governor had the rank of praeses. The rank praesides provinciae appeared in the $2705 \mathrm{AD}^{23}$

In consideration of the then contemporary historical and geographical transregional/regional context and implementation of the Roman imperial rule, the first version of the translation by T. Kauchtschischwili is neither plausible nor

\footnotetext{
${ }^{15}$ Erskine 1991, 274.

${ }^{16}$ Erskine 1991, 275.

${ }^{17}$ Erskine 1991, 272.

${ }^{18}$ Cf. Bouras 2016, $2 \mathrm{O}$.

${ }^{19}$ Cf. Bouras 2016, 202.

${ }^{20}$ Cf. Étienne 1990, 127-149.

${ }^{21}$ Cf. Accame 1946, 234-241.

${ }^{22}$ Demandt 1998, 216.

${ }^{23}$ Radke 1956, col. 598-614.
} 
realistic. The locals from the island of Naxos could hardly afford any office corresponding to the title of BA $\Sigma \mathrm{I} \Lambda \mathrm{I} \Sigma \Sigma \mathrm{A}$ (Lat. Regina, -ae).

I consider that the ring has an engraved corrupted Greek inscription (BACI $\Lambda$ ICCA OY $\Lambda$ ПIANA $(Z)$ IA). The third letter from the end of the last word is depicted as a Greek rotated sign for Z (Zeta). However, it could have been the sign for $\Sigma$ (Sigma). Furthermore, some (the three inscriptions) ancient Greek inscriptions, which originated in Rome ${ }^{24}$ contain that the same symbol (i.e., the 'rotated' Z) which was engraved on Ulpia's ring and stands for the Greek 'Sigma'. In the three above-mentioned inscriptions from Rome, the "rotated Z" represents an archaic symbol of $\Sigma$ 'Sigma'. Thus, it may be an inflected form of the letter. In addition, rotated and changed signs appear in the word for BACINICCA, where the Latin C (cē) stands for the Greek $\Sigma$ (Sigma).

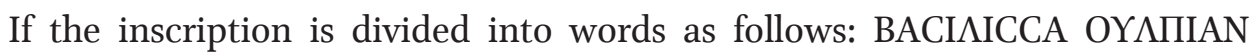
A $\Sigma$ IA ('A $\sigma i \alpha$, E.A.). Transliteration: Bac[Lat. cē]ili[Lat. double cē]a Oylpian Asia. Reconstructed the inscription reads as: "The Ruler/ Queen [a female form from $\left.\beta \breve{\alpha} \sigma \grave{\imath} \lambda \varepsilon \dot{\varsigma} \varsigma=\beta \alpha \sigma^{\prime} \lambda \iota_{1 \sigma \sigma \alpha}\right]$ Oylpian of Asia. I presume that this version can lead to a much more plausible conclusion, what will be discussed below.

As for the word ' $\mathrm{A} \Sigma(\mathrm{Z}) \mathrm{IA}$ ', it may be an inflected form (in a regional dialect) of

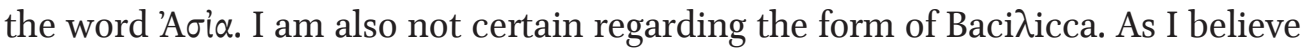
it should be stated as $\beta \breve{\alpha} \sigma \breve{\imath} \lambda \varepsilon ı \alpha$ or $\beta \alpha \sigma i \lambda ı \sigma \sigma \alpha$, and perhaps it was again a Romanised version of the Greek letter sigma. The identical interchange of Greek letter sigma with Latin letter C (cē) appears in above mentioned Rhodian inscription -

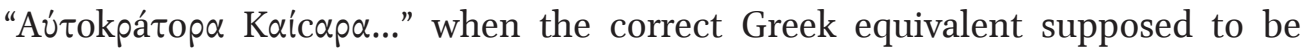
Kaíapa. ${ }^{25}$

Summarizing the above, we may conclude that the depicted female had the highest political position in the Late Roman Empire. The female named as Oylpian wore the highest title of BACINICCA. The Greek version for the term "the ruler" could be very common and acceptable for the Greek-speaking Roman Orient and was often used in Imperial media.

\section{The Secret of BACIAICCA, who was BACIAICCA OYAПIAN?}

As being a member of a particular royal or imperial family, owing to her privileged official political position, we identify the female individual through the then historical context. For this position, the most suitable candidacy seems to be Roman Empress Ulpia Severina.

\footnotetext{
${ }^{24}$ For these texts cf. $A E$ 190o, September-December, pp.58, text no 208 (lecture de. M. Cici etc.).

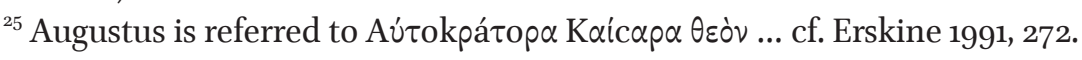


During the reign of Emperor Lucius Domitius Aurelianus Augustus (270-275 AD) the Romans regained control of the Caucasia briefly. His wife, Ulpia Severina, according to the Historia Augusta, was most likely the daughter of Ulpius Crinitus, a man of consular rank in Rome during the time of Valerian (HA, Vita Aur. $13.2 ; 14.7-15.2 ; 45.5 ; 50.2$ ). Severina received the title Augusta only in the autumn of $274 \mathrm{AD} .{ }^{26}$ Her ruling status with the several relevant titles are known to us as domina, mater castrorum, mater castrorum et senatus et patriae, and Piissima Augusta (274 AD).

On the coins, there is an inscription in which Severina is referred to as an incarnation of the goddess of victory. ${ }^{27}$ Besides the coins celebrating the Concordia of the Empire, Severina's coins also featured the goddesses Venus and Juno, two standard deities for empresses. ${ }^{28}$ In addition to that, certain late issues of coins minted in the name of Severina belong to the period following her husband's assassination in $275 \mathrm{AD}$ during the so-called Interregnum and indicate that the government of the Empire was carried on in her name, whether or not with the co-operation of the senate. Traces of the same system were found at Ticinum and Antioch after the emperor's death. It appears that the last issues bearing the obverse of Severina included almost exclusively coins with the legend CONCORDIA MILITVM, an entirely appropriate legend for a lady trying to maintain control of, or assert control over, the Empire through harmonious relationship between the leader and the military. ${ }^{29}$ From the Antiochian mint came a coin of Severina bearing the legend CONCORDIA AVG, which is striking for the use of the singular AVG instead of the earlier AVGG. ${ }^{3 \circ}$

The inscriptions mentioning Ulpia Severina in transregional context should be divided into two categories and can be distinguished according to the language and form of her name. Geographically, the Latin inscriptions are related to Italy, Spain, and Africa, while the Greek inscriptions originated in Pannonia and Asia (Smyrna, Lydia). The Latin versions of her name are mostly stated as ULPIAE SEVERINAE or ULPIE SEVERINE ${ }^{31}$, whereas two Greek inscriptions present her

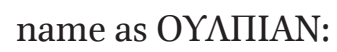

\section{OYAПIAN CEYH \\ PEINAN OEAN}

\footnotetext{
${ }^{26}$ Watson 2003, 114.

${ }^{27}$ Weinstock, 'Victoria', RE 8. A2, 1958, 2501-42.

${ }^{28}$ Cf. RIC V1, 316, no. 7 .

${ }^{29}$ Ricciardi 2007, 294.

${ }^{30}$ Watson 2003, 115 .

${ }^{31}$ Ricciardi 2007, 303.
} 




It can be seen that in the cases of these Greek inscriptions (from Pannonia and Asia) we have the same form 'OY $\Lambda$ ПIAN' as it in the inscription on the golden ring from Mtskheta. As for the geographical term for 'Asia', it frequently appears in the Greek and Latin personal inscriptions as a designator for the geographic region as well as for the imperial administrative unit. If my interpretation is correct, such a conception corresponds closely to the contemporary historical situation (to proclaim empress Ulpia as 'a ruler of 'Aбia' in the Roman province of Asia) and should be considered as an imperial political decision to establish the empress cult and authority in Oriental provinces of Asia.

I presume that the golden ring with a carnelian intaglio was made circa 274$275 \mathrm{AD}$, in the last year of the reign of Aurelian or immediately after the murder of Emperor when Ulpia herself became Empress.

\section{Conclusion}

One can often detect a political or social agenda associated with certain individuals in the portraits of the Late Roman period. The 3 rd century AD represents a clear case in point. The dissemination of personal and political propaganda would be particularly useful in case of communication with subjected countries in order to seize control over the peripheral parts of the Empire.

In the portrayal of 'Oriental Augusta,' we observe widely recognizable traits and iconography very similar to the then contemporary Greco-Roman and oriental styles. The Roman royal woman depicted in Hellenistic- Oriental garments was imperial artistic imagery in order to assert authority over the eastern parts of the Empire. The depiction and formulation of well-understandable imagery with explanatory texts would have been essential to the promotion of confidence to the Roman power in the Roman Orient.

\footnotetext{
${ }^{32}$ The inscription comes from Pannonia, cf. Ricciardi 2007, 303; $A E$ 1927, 81.

${ }^{33}$ The inscription comes from Asia (Smyrna, Lydia). Cf. Ricciardi 2007, 303. AE 1900, 145 [p. 79. A Boghdeylik].
} 


\section{REFERENCES}

Abbreviations for Frequently Cited Corpora

AE L’Année Épigraphique, Revue Des Publications Épigraphiques, Relatives À L'Antiquité Romaine, Presses Universitaires de France.

HA Historia Augusta, the Life of Aurelian. The Latin text and translation by Susan H. Ballou and Hermann Peter. The English translation is by David Magie. Loeb Classical Library edition, 1932.

RIC Roman Imperial Coinage.

Accame, S. (1946) Il dominio Romano in Grecia dalla Guerra Acaica ad Augusto. Rome.

Alcock, S. E. (1993) Graecia Capta: The Landscapes of Roman Greece. Cambridge.

Apakidze, A., Kipiani, G., Nikolaishvili, V. (2004) "A Rich Burial from Mtskheta (Caucasian Iberia)," G. R. Tsetskladze, ed. Ancient West and East 3(1). Leiden andBoston, 104-123.

Bouras, C. (2016) "The Geography of Connections: A Harbour Network in the Aegean Sea during the Roman Imperial Period?" K. Höghammar, B. Alroth and A. Lindhagen, eds. Ancient Ports, the Geography of Connections. Uppsala, 202-223.

Budin, S. L. (2016) Artemis. London.

Butcher, K. (2003) Roman Syria and the Near East. Los Angeles: Getty Publications.

Demandt, A. (1998) Geschichte der Spätantike Das Römische Reich von Diocletian bis Justinian 284-565 n. Chr. München.

Erskine, A. (1991) “Augustus and Rhodes," Zeitschrift für Papyrologie und Epigraphik 88, 271275 .

Étienne, R. (1990) Ténos II. Ténos et les Cyclades du milieu du IVe siècle av. J.-C au milieu du Ille siècle ap.J.-C. Paris.

Kauchtschischwili, T. (2003) "Neuentdeckte Gegenstände mit Griechischen Inschriften aus Mzcheta," R. Gordeziani, ed. Phasis 5-6, Institute of Classical Philology, Byzantine and Modern Greek Studies, Iv. Javakhishvili Tbilisi State University.Tbilisi, 136-142.

Millar, F. (1966) "The Emperor, the Senate and the Provinces," The Journal of Roman Studies $56,156-166$.

Radke, G. (1956) "Praeses," Realencyclopädie der Classischen Altertumswissenschaft. Supplementband VIII, Achaios-Valerius. col. 598-614.

Ricciardi, R. (2007) Where Did All the Women Go: The Archaeology of the Soldier Empresses. Doctoral Thesis, University of Cincinnati. Cincinnati.

Şare, T. (2011) Dress and Identity in the art of Western Anatolia: The Seventh through Fourth Centuries BCE. Doctoral Thesis, State University of New Jersey. New Brunswick.

Suny, R. G. (1994) The Making of the Georgian Nation. Indianapolis.

Tracene, H. (2011) The Visual Representation of Livia on the Coins of the Roman Empire. Doctoral Thesis, University of Albert. Edmonton, Alberta.

Watson, A. (2003) Aurelian and the Third Century. London and New York.

Weinstock, S. (1958) "Victoria," RE Pauly-Wissowa, Real Encyclopädie der klassischen Altertumswissenschaft 8. A2, 2501-42. 